\title{
SPIRITUALITAS PETUNGAN: KONSTRUK PSIKOLOGIS PENENTUAN WAKTU PERNIKAHAN PADA ORANG JAWA
}

\author{
Abdul Latif $A A$ \\ Program Studi Psikologi \\ Universitas Islam Raden Rahmat Malang \\ Jalan Raya Mojosari No. 02 Kepanjen, Malang \\ email: abdullatif@psikologiliyan.com
}

\begin{abstract}
This research aims to get the dynamics of decision making in determining the time of marriage on the Javanese community by using "petungan" constructs. Until now the Javanese community still persists and trusts there is spesific time, so-called good time, to get married. This is a phenomenological qualitative research to reveal the meaning and psychological dynamics of the used "petungan" in reasoning the time of marriage.

"Petungan" as a reasoning in determining the time of marriage comes from tradition and individual experience the reflects of user psychological dynamics. Psychological representation in the use "petungan" to determine the time of marriage is (1) negative bias - efforts to avoid psychological anxiety, (2) constructs expectation - "petungan" symbolic value expected, (3) "petungan" spiritual - achievement of psychological expectations.
\end{abstract}

Keyword: Petungan; decision making; psychological construct; spirituality

\begin{abstract}
Abstrak - Penelitian ini bertujuan untuk memperoleh dinamika pengambilan keputusan dalam menentukan waktu pernikahan pada masyarakat Jawa dengan menggunakan konstruk petungan. Sampai saat masyarakat Jawa masih bertahan dan percaya bahwa waktu-waktu tertentu disebut sebagai waktu yang baik untuk melangsungkan pernikaham. Penelitian ini merupakan penelitian kualitatif fenomenologis untuk mengungkap makna dan dinamika psikologis dari penggunaan petungan dalam pertimbangan waktu pernikahan.

Ditemukan gambaran kontinum penggunaan petungan sebagai petimbangan dalam menentukan waktu pernikahan bersumber dari akar tradisi dan pengalaman individu yang menggambarkan dinamika psikologis pengamalnya. Representasi psikologis dalam penggunaan petungan dalam menentukan waktu pernikahan tersebut adalah: (1) bias negatifitas - upaya menghindari kecemasan psikologis, (2) ekspektasi konstruktifistik - merupakan nilai simbolik petungan yang diharapkan dan (3) spiritualitas petungan - sebagai pencapaian harapan psikologis
\end{abstract}

Kata kunci: Petungan; pengambilan keputusan; konstruksi psikologis; spiritualitas

\section{PENDAHULUAN}

Masyarakat Jawa memiliki pemikiran dan pandangan hidup sebagai bagian dari tradisi dan kebudayaan Jawa. Mulder (2001) mengemukakan tradisi Jawa bersumber dari pemikiran kosmologi, mitologi, dan mistisisme Jawa dan menjadi pokok praktik dalam kehidupan sehari-hari orang Jawa. Petungan merupakan salah satu tradisi pemikiran dan 
pertimbangan dalam tindakan orang Jawa yang dihubungkan dengan sistim penanggalan (kalender) Jawa.

Pada bulan-bulan tertentu, kalender Jawa seperti bulan besar dan bakda mulud pada masyarakat Jawa banyak dilangsungkan hajat pernikahan. Namun sebaliknya, pada bulan Selo, Suro dan Safar tidak banyak, bahkan tidak ditemukan masyarakat Jawa yang melangsungkan hajat pernikahan. Dalam data pencatatan pernikahan di KUA kecamatan Rambiuji setelah di konversikan ke dalam bulan dalam kalender Jawa diperoleh gambaran sebagaimana berikut:

Tabel 1.

Jumlah penikahan berdasarkan bulan

\begin{tabular}{|c|c|c|c|}
\hline Tanggal & Bulan & & \\
\hline $1-8$ Oktober '10 & Sawal* & 14 & 3 \\
\hline $9 \mathrm{Okt}-7 \mathrm{Nov}$ ' 10 & Selo & 15 & 3 \\
\hline 8 Nov -7 Des ' 10 & Besar & 153 & 29 \\
\hline $\begin{array}{r}8 \text { Des '10 - } 6 \text { Jan } \\
' 11 \\
\end{array}$ & Suro & 6 & 1 \\
\hline 7 Jan -3 Feb '11 & Safar & 32 & 6 \\
\hline $4 \mathrm{Feb}-5 \mathrm{Mar}$ '11 & Mulud & 24 & 4 \\
\hline $6 \mathrm{Mar}-4 \mathrm{Apr}$ '11 & Bakda Mulud & 121 & 23 \\
\hline $5 \mathrm{Apr}-4 \mathrm{Mei}$ '11 & Jumadil awal & 42 & 8 \\
\hline 5 Mei -2 Jun '11 & Jumadil Akhir & 83 & 16 \\
\hline 3 Jun -2 Jul '11 & Rejeb & 30 & 6 \\
\hline $3 \mathrm{Jul}-13 \mathrm{Jul}$ '11 & Ruwah * & 14 & 3 \\
\hline
\end{tabular}

Sumber: diolah dari database SIM -K KUA Kecamatan Rambipuji

Fenomena penggunaan bulan tertentu untuk melangsungkan pernikahan pada masyarakat Jawa bukan merupakan sesuatu yang kebetulan, namun merupakan pilihan tindakan yang berhubungan dengan konstruk kebudayaan dan kearifan lokal masyarakat Jawa.

Penggunaan petungan pada masyarakat Jawa merupakan konstruk dominan (Danandjaja, 1988) di mana tradisi petungan menjadi lembaga yang memiliki konsep ideal tentang bagaiamana orang Jawa bertindak, berkepribadian. dan bersikap dalam lingkungan kebudayaannya, sehingga petungan dapat dikatakan sebagai cara orang Jawa menentukan waktu pernikahan berdasarkan ketersediaan konstruk kebudayaan dominan. Masih digunakannya petungan dalam menentukan waktu pernikahan dipengaruhi oleh adat-istiadat 
(Nila, 2010), persepsi positif pada tradisi petungan (Listyana \& Hartono, 2013) serta kepercayaan orang Jawa bahwa ada kekuasaan yang Maha Kuasa atas nasib mereka dan berhubungan dengan penetuan waktu berdasarkan petungan (Hartono, 2016).

Fenomena pengambilan keputusan yang idealnya bersifat rasional, prediktif, dan akurat, pada masyarakat Jawa dalam menentukan waktu pernikahan cenderung menggunakan pemikiran asosiatif simbolik dan bersifat pre-logis berdasarkan nilai simbolis heroskopis petungan (Endraswara, 2006).

Pertimbangan petungan dalam pengambilan keputusan pada masyarakat Jawa ini tidak dapat dilepaskan dari pandangan hidup masyarakat Jawa ke dalam bentuk mistis atau pengetahuan spiritual, memadukan tidak hanya pengetahuan pikiran namun sebagai pengalaman utuh sepanjang rentang kehidupan. Dengan mencoba memahami bagaimana masyarakat Jawa dalam praktik tradisi petungan waktu pernikahan dapat menjadi dasar pemikiran memunculkan psikologi indigenous adat Jawa dan menggambarkan bagaimana masyarakat Jawa memiliki pandangan dan pemahaman pada dimensi psikologinya sendiri.

Berdasarkan pemaparan di atas, yakni mengenai fenomena praktik pengambilan keputusan waktu pernikahan pada masyarakat Jawa menggunakan petungan, menarik untuk dilakukan penelitian lebih lanjut bagaimana dinamika psikologis masyarakat Jawa dalam pengambilan keputusan waktu pernikahan menggunakan petungan Jawa.

\section{Petungan Jawa dan Konstruksi Sosial Psikologis}

Petungan Jawa merupakan perangkat kebudayaan yang pada masyarakat Jawa berdasarkan nilai-nilai yang disimbolkan dalan sisitim kalender Jawa. Gertz (dalam Syaifudin, 2006) mengemukakan kebudayaan merupakan sistim keteraturan dari makna dan simbol-simbol, ditransimisikan secara historis untuk mengontrol perilaku, sumber ekstrasomatis, dan informasi sehingga perlu dipahami, diterjemahkan dan melalui proses interpretasi.

Petungan sendiri bagi masyarakat Jawa adalah informasi akan nilai baik dan buruknya waktu tertentu untuk melaksanakan suatu kegiatan tertentu, sehingga dengan petungan tersebut juga masyarakat Jawa mempertimbangkan pengambilan keputusan. Bagi masyarakat Jawa, kalender Jawa tidak hanya berfungsi sebagai penunjuk hari (waktu), 
melainkan juga menjadi dasar Petungan, yaitu perhitungan baik dan buruk berdasarkan waktu kalender tersebut (Hariwijaya, 2006).

Dalam petungan Jawa terdapat banyak perhitungan yang menjadi kearifan lokal, salah satunya adalah petungan salaki rabi atau petungan pernikahan serta baik buruknya hari untuk melangsungkan pernikahan (Hartono, 2016).

Konstruksi nilai petungan pernikahan banyak diterangkan dalam kitab-kitab prombon Jawa sebagaimana berikut:

"Ada sabda utusan kepada para mukmin mengenai bulan perkawinan (sebagai berikut)". Agar diketahui, tentang orang yang bersuami istri akan mendapat papa jika bulannya jelek, akan selamat bila bulannya baik. Seyogyanya diketahui, jika bulan Muharram jauhilah, sebab alamat suami istri akan banyak utang. Bulan sapar juga tidak baik, entah akan apa yang akan dijumpai. Bila kawin pada bulan Rabiul Awal, salah satu akan meninggal. Jika kawin pada bulan Rabiul Akhir, akan selalu marah dan berbantah. Jika kawin dalam bulan Jumadil Awal, akan mendapat durhaka dari tuhan dan sering kecurian, bebuat serong, dan apabila ketahuan pasti akan mendapat malu besar. Bila kawin pada bulan Jumadil Akhir, akan kaya emas dan uang. Kawin pada bulan Sakban akan mendapat keselamatan, segala pekerjaan akan berhasil baik. Kawin di bulan Ramadan durhaka, banyak pekerjaan iblis. Kawin pada bulan Syawal tidak baik, akibatnya sakit-sakitan. Kawin di bulan Dzulkaidah sering susah sekali, sedangkan kawin di bulan besar, segala tindakannya selamat".

Serat Centini - Pakubuwono (1991)

Juga dalam kitab primbon Lukmanakim Adamakna (Tjakraningrat, 2008) telah disusun tabel hari untuk melangsungkan pernikahan berdasarkan saat lahirnya kedua mempelai sebagai berikut. 
Tabel 2.

Tabel Hari Akad

\begin{tabular}{llll}
\hline \multicolumn{1}{c}{ Lahire Menten } & \multicolumn{1}{c}{ hari akad } & \multicolumn{2}{c}{ Watake } \\
\hline Jum. Lg - St Phng & Kamis. Klw & Cacad & Meh Jangkep \\
\hline Sls. Klw- Jum. Pn & Kamis. Wg & Luwih becik & Jangkep \\
\hline Kms. Ph- Akad. Wg & Selasa. Klw & Becik & Meh Jangkep \\
\hline Rabo. Lg- Kms. Pn & Senen. Klw & Becik & Jangkep \\
\hline Akad. Pn- Kms. Wg & Jum. Klw & Cacad & Jangkep \\
\hline Senen. Wg- Senen Wg & Kamis Klw & Becik & Gothang \\
\hline Setu. Wg- Kms. Lg & Senen. Klw & Rada Cacad & Jangkep \\
\hline Senen. Pn-Kms. Pn & Jum/akad. Klw & Rada Cacad & Meh Jangkep \\
\hline Senen. Lg- Jum. Lg & Akad. Klw & Cacad & Gotang \\
\hline ... dst & .. dst & ...dst & ... dst \\
\hline
\end{tabular}

\section{Katrangan:}

1. cacad-gothang: ini berarti tidak jodoh, jika di teruskan banyak rubeda

2. becik-gothang: ini juga tidak jodoh, namun jika diteruskan rubeda-nya lebih enteng

3. cacad-meh jangkep: ini kurang jodoh. bias diteruskan

4. cacad-jangkep lan rada cacad-meh jangkep: ini agak berjodo, dapat diteruskan

5. rada cacad-meh jangkep lan becik-meh jangkep: ini dinamakan baik jodoh dan baik

6. becik-jangkep lan luwih becik-jangkep: ini dinamakan jodoh disebut sebagai curiga manjing warangka

Penggunaan bulan tertentu untuk melangsungkan pernikahan pada masyarakat Jawa pada kenyataannya sejalan dengan konsesus nilai adat-istiadat, kepercayaam yang berkembang di dalam tradisi petungan, menjadi fakta sosial bulan tertentu banyak dilangsungkan pernikahan, demikian sebaliknya. Durkheim (dalam Ritzer \& Goodman, 2007) menyebutkan bahwa kultur dan institusi sosial merupakan fakta sosial non-marerial dan menjadi simpul masyarakat karena kuatnya nilai moralitas bersama.

Keberlangsungan penggunaan petungan sendiri merupakan adat-istiadat yang turuntemurun, bersifat resisten, dan dibentuk bahkan di luar kesadaran individu (Ritzer \& Goodman, 2007). Adat-istiadat sendiri merupakan konstruksi sosial yang dimiliki bersama dalam waktu yang lama (Newcomb, Turner \& Converse, 1981). Putra (2008) menegaskan konstruksi sosial dalam psikologi menjadi kajian penting di tengah kejumudan psikologi postivistik mengenai bagaimana yang manusia bertindak dan "menjadi". Parson (dalam Koentjoroningrat, 1990) dalam sistem tindakan manusia meletakkan sistem kebudayaan sebagai kekuatan utama yang mengendalikan sistem sosial, kepribadian, dan organis, dan sebaliknya sistem yang di bawah menjadi kekuatan dari sistem di atasnya. 
Penggunaan petungan dalam menentukan waktu pernikahan merupakan suatu tindakan dengan wajah sosial, merupakan tuntutan kebiasaan dan tradisi di masyarakat (Hall \& Lindzei, 2005). Budaya adalah konstruk psikologis (Matsumoto, 2008), mengacu pada sejauh mana sekelompok orang bersama-sama menganut sikap, nilai, keyakinan serta perilaku, sehingga fenomena bulan tertentu berlangsung banyak pernikahan merupakan representasi sosial pikologis (Hogg \& Voughan, 2005) dari nilai-nilai dalam tradisi petungan. Matsumoto (2008) menyatakan bahwa budaya sebagai konstruk psikologis mengacu pada serangkaian sikap, nilai, keyakinan, dan perilaku berdasarkan nilai dalam kebudayaan tersebut.

Petungan Jawa sebagai sistem adat-istiadat dengan seperangkat nilai simboliknya, dijelaskan Jung (Dalam Hall \& Lindzey, 2005) bahwa lambang merupakan usaha untuk menjelaskan sesuatu yang sama sekali belum diketahui atau sesuatu yang belum ada menggunakan analogi, sehingga lambang akan diketahui dengan menguraikan lambang tersebut. Jung juga menegaskan bahwa lambang berfungsi memuaskan impuls insting dan sebagai bahan arketipe, sehingga penggunaan petungan bagi masyarakat Jawa dalam menentukan waktu pernikahan adalah sebuah usaha untuk menjelaskan harapan nasib berdasarkan nilai yang dikonstruksikan dalam kebudayaan.

\section{METODE}

\section{Partisipan}

Psikologi fenomenologis dimaksudkan untuk menjelaskan situasi yang dialami oleh individu. Partisipan dalam penelitian kualitatif tidak menekankan pada keterwakilan, sehingan partispan dalam penelitian ini dilakukan secara purposive (Smith, 2009). Partisipan merupakan anggota masyarakat di desa Kaliwining dan seluruhnya berakar pada kebudayaan Jawa. Partisipan terdiri dari beberapa subyek yang semuanya terlibat langsung dalam kegiatan perkawinan mulai dari mempelai, orangtua dan tokoh masyarakat yang terlibat dan menjadi sumber bertanya perilahal petungan waktu pernikahan. Pendidikan partisipan terbagi ke dalam kelompok pendidikan tinggi (pada mempelai), pendidikan rendah (pada orangtua) dan pendidikan pesantren (rata-rata tokoh masyarakat). 
Pada tahapan operasional, untuk sampai pada informan mula-mula peneliti terlibat secara aktif dalam kehidupan sehari-hari masyarakat untuk dapat menentukan beberapa informan yang sesuai dengan syarat terlibat dalam penentuan waktu pernikahan. Akhirnya peneliti menetapkan informan penelitian sebagaimana berikut:

1. Subyek pertama dan kedua adalah mempelai yang memahami dalam penentuan waktu pernikahannya terdapat perbincangan perihal waktu pernikahannya dengan menggunakan prinsip nilai dalam petungan.

2. Subyek ketiga dan keempat adalah orangtua yang keterlibatannya dalam menentukan waktu pernikahan anaknya mengikuti konstruk adat-istiadat sistem petungan serta mampu menceritakan bagaimana proses penentuan waktu tersebut.

3. Subyek kelima adalah para tokoh masyarakat yang sering dilibatkan dan menjadi tempat bertanya perihal waktu pernikahan oleh masyarakat setempat, juga beberapa subyek lain yang melengkapi beberapa informasi yang relevan.

\section{Desain}

Dalam menentukan waktu pernikahan, masyarakat Jawa berada dalam satu konstruk kebudayaan untuk memilih waktu yang dinilai dan dipercaya sebagai waktu yang baik. Dalam petungan, pada tiap bulan yang dipilih untuk melangsungkan pernikahan memiliki makna peramalan nasib baik dan buruknya pernikahan. Kesadaran masyarakat Jawa untuk memilih waktu tertentu merupakan pengalaman yang dialami dalam konteks sistim tradisi petungan waktu pernikahan. Dikarenakan untuk mengungkap dan mendeskripsikan pengalaman psikologis subyek pada fenomena tersebut, digunakanlah pendekatan fenomenologis.

\section{Prosedur}

Pengumpulan data dilakukan melalui metode wawancara mendalam dan naratif. Wawancara dilakukan pada subyek di rumahnya dengan suasana santai dan untuk memperoleh data terkait dengan proses penentuan waktu pernikahan. Selain itu pengamatan dilakukan untuk memperoleh gambaran situasi dan memahami makna dari sudut pandang subyek. Wawancara dilangsungkan satu sampai dua kali pada beberapa subyek. 


\section{Teknik Analisis}

Berdasarkan hasil wawancara yang peneliti lakukan, analisis pada data yang diperoleh mengacu pada konsep dan disiplin ilmu psikologi. Prosedur analisis data dilakukan melalui tahapan sebagaimana dikemukakan oleh Smith (2009), sebagai berikut: mengorganisasi seluruh data yang diperoleh, membuat catatan penting, mengembangkan tema, mecari hubungan antar tema, mencari pola antar tema dan subyek kemudian mendeskripsikan sebagai deskripsi fenomenologis.

\section{ANALISIS DAN HASIL}

\section{Deskripsi dan Pengetahun Subyek Terhadap Petungan}

Subyek 1 adalah pasangan menikah pada 2 November 2007 dan telah memiliki seorang putri, memiliki latar belakang pendidikan sarjana muda. Subyek 1 menyampaikan tidak mempercayai peramalan petungan dan mencontohkan terkait dengan pindah tempat tinggal berlangsung dengan cepat tanpa mempertimbangkan petungan. Namun demikian subyek 1 menuturkan bahwa pernikahannya sempat ditunda karena alasan "berat sebelah". Subyek mengikuti kehendak untuk mundur satu minggu dari hari yang sudah ditepakan. Sekalipun menyatakan tidak percaya dengan nilai peramalan petungan, subyek meyakini bahwa segala sesuatunya tidak ada yang terjadi secara kebetulan dan apa yang manusia pikirkan seerta yakini dapat terjadi.

Subyek 2 adalah seorang santri dan menyampaikan bahwa dirinya tidak mempercayai petungan namun menegaskan bolehnya percaya karena sebagai orang Jawa selama tidak bertentangan dengan ajaran Islam. Subyek juga memberikan penekanan bahwa peramalan nilai petungan terdapat benar dan salahnya. Sekalipun subyek menegaskan bahwa penentuan waktu pernikahannya tidak dihubungkan dengan perimbangan petungan, waktu pernikahannya yang bertepatan dengan jumadil akhir tersebut dikonsultasikan dengan guru di pesantren. Subyek juga menyadari bahwa bulan yang dipilih merupakan bulan yang umum masyarakat gunakan untuk melangsungkan pernikahan.

Subyek 3 adalah orangtua yang menikahkan putri pertamanya. Subyek menuturkan bahwa dirinya tidak mengetahui bagaimana menentukan waktu pernikahan dan menegaskan bahwa semua itu sudah ada dalam kitab mujarrobat. Subyek juga menceritakan bahwa 
menggunakan primbon merupakan amalan masyarakat kejawen Islam dan peninggalan para wali. Petungan dipersepsi sebagai pola yang rumit dan detail, sehingga subyek menanyakan tentang waktu pernikahan putrinya pada tokoh yang mengerti tentang perihal tersebut. Penetuan hari pernikahannya didasarkan pada perhitungan pada nilai dan keterangan "pangan" yang berarti baik. Subyek pada akhirnya memberikan penekanan bahwa petungan sebagai usaha mencari yang terbaik, bergantung pada niatnya karena segala sesuatunya Tuhan yang menentukan.

Subyek 4 juga merupakan orangtua yang menikahkan putrinya pada bulan jumadil akhir. Subyek menegaskan bahwa petungan merupakan peninggalan dan warisan orang tua yang masih digunakan sampai saat ini. Dalam pandangannya, petungan pernikahan sebagai sesuatu yang rumit dan merkomendasikan untuk bertemu dengan salah satu tokoh masyarakat.

Subyek 5 adalah satu tokoh masyarakat yang memahami pengetahuan petungan dan sumber informasi pertimbangan pernikahan subyek 3 . Terdapat tiga bulan yang baik untuk melangsungkan pernikahan, yaitu: jumadil akhir, ruwah dan besar, seperti telah diterangkan dalam kitab mujarrobat. Setelah itu subyek juga menjelaskan menentukan hari pernikahan dengan menjumlahkan neptu hari dan pasaran pernikahan untuk diperoleh keterangan sandang, pangan, loro, pati. Jika perhitungan hati jatuh pada loro dan pati, sebaiknya dihindari hari tersebut. Subyek menekankan bahwa penggunaan petungan merupakan adat, terkadang cocok, sebagai ramalan menjalankan aturan. Subyek menegaskan kegundahan karena beberapa orang telah meninggalkan adat karena sudah "kumpul" maka dinikahkan tanpa mempertimbangkan petungan waktu nikah, baru di kemudian hari memperbarui akad dengan mencari waktu yang baik. Subyek menekankan adat-istiadat Jawa tidak boleh ditinggalkan, karena kita tinggal di Jawa.

Subyek 6 adalah seorang guru thoriqoh. Subyek tidak banyak menjelaskan bagaimana menentukan waktu pernikahan menggunakan petungan. Subyek cukup menjelaskan berulang-ulang bahwa bulan yang baik untuk melangsungkan pernikahan adalah bulan jumdil akhir, safar dan besar.

Subyek 7 adalah seorang ustad lulusan pesantren. Subyek menejelaskan bahwa dalam membantu menentukan waktu pernikahan tidak menggunakan pedoman petungan Jawa, melainkan menggunakan pedoaman kitab al-ma'tsarul al-falaki. Subyek menegaskan terdapat kesamaan kitab yang digunakan dengan kitab petungan Jawa. Subyek memiliki penilaian yang sama, bahwa bulan yang baik untuk melangsungkan pernikahan adalah bulan 
besar antara tanggal sepuluh sampai empat belas, adapun di bawahnya ataupun di atasnya jika perhitungan neptu-nya bagus, tetap tidak dapat meningkat.

Pemahaman subyek penelitian di atas juga dikuatkan kepala KUA kecamatan Rambipuji bahwa terdapat tren pencatatan pernikahan yang terjadi setiap tahunnya. Peningkatan pencatatan pernikahan terlihat ketika bulan besar dan mendekati puasa, namun sebaliknya pada bulan suro dan selo adalah yang paling tidak ada pencatatan pernikahan. Demikian juga disampaikan penyuluh bimbingan Islam di lingkungan KUA kecamatan Rambipuji juga menyampaikan bahwa sekalipun semua hari baik, terdapat hari yang utama, seperti Jumat sebagai sayyidul ayyam dan rosulullah berpuasa di hari Senin yang menjadi hari kelahirannya. Juga ditegaskan, kalau seseorang tahu bahwa hari itu dikatakan sebagai hari yang tidak baik, dia mungkin tidak akan menggunakan hari tersebut.

\section{Makna Petungan Pernikahan Jawa}

Pertama, kebudayaan sebagai konstruk psikologis. Fenomena bulan-bulan tertentu seperti besar, ruwah dan jumadil akhir banyak dipilih untuk melangsungkan pernikahan merupakan representasi sosial dan merupakan pemahaman subyek secara umum yang berkembang di dalam masyarakat Jawa bahwa bulan-bulan tertentu baik untuk melangsungkan pernikahan, sebaliknya pada bulan-bulan lain yang sangat tidak banyak dilangsungkan pernikahan merupakan bulan yang kurang baik bahkan tidak baik untuk melangsungkan pernikahan. Pemahaman masyarakat pada praktik menentukan waktu pernikahan merupakan informasi, baik secara sadar maupun tidak sadar, berpikir, bersikap, mempercayai dan bertindak sesuai dengan konstruksi nilai yang berkembang pada sistim kebudayaan. Pemahaman masyarakat Jawa tentang waktu tertentu untuk melangsungkan pernikahan bukan semata-mata menyebutnya sebagai tradisi atau tinggal menjalani, namun lebih jauh menegaskan relasi antara tradisi dan pemahaman masyarakat yang membimbing mereka melakukan tindakan yang terpola. Jika diperhatikan dengan seksama, tingginya waktu tertentu unuk melangsungkan perkawinan sejalan dengan atribut nilai peramalan baik buruk yang tersusun di dalam kitab primbon maupun petungan.

Kedua, menghindari kecemasan psikologis. Dalam petungan pernikahan Jawa terdapat konstruksi nilai bulan tertentu sebagai bulan yang baik dan sebaliknya merupakan bulan yang kurang baik. Pernyataan subyek penelitian yang menegaskan bulan-bulan yang baik merupakan framing. Penegasan bulan yang baik oleh sebagian besar subyek 
menunjukkan bahwa pilihan yang tidak beresiko lebih dipertegas keberadaannya. Selain itu, informasi bahwa waktu tertentu disebut sebagai kurang baik pada subyek 1 dan memilih untuk menuruti untuk mundur waktu pernikahan satu minggu berikutnya menegaskan bingkai keputusan yang menghindari resiko. Pernyataan subyek 3 dan 5 menegaskan bahwa penggunaan pertimbangan waktu yang baik merupakan suatu usaha, bahkan subyek 7 menegaskan kecemasan, sekalipun perhitungan neptu yang baik, maka tidak akan mengubah jika pilihan waktunya di luar antara tanggal 10 sampai 14 bulan besar. Nilai petungan merupakan informasi yang bersifat asosiatif simbolik dan bertolak pada realitas empiris atau makna yang berkembang di masyarakat. Dalam praktiknya bertentangan dengan konfigurasi dominan di masyarakat dalam menentukan waktu pernikahan akan menimbulkan konflik, sehingga menggunakan petungan juga bermakna untuk menghindari kecemasan psikologis sebagai efek dari bias negativitas yang berkembang di masyarakat.

Ketiga, pencapaian harapan psikologis. Penggunaan petungan dalam menentukan waktu pernikahan pada masyarakat Jawa didasarkan pada prinsip menghindari apes (situasi kurang beruntung) dan mencapai kebahagiaan sesuai dengan makna simbolik dari waktu yang dipilih. Petungan menjadi jalan untuk ngastiti (hati-hati) setelah itu yakin dan tawakkal. Petungan sendiri bagi masyarakat Jawa dipahami sebagai usaha untuk mendapatkan sesuatu yang terbaik di kemudian hari berdasarkan prinsip dasar petungan. Petungan yang merupakan praktik mistik-magis berlangsung sebagai pola tindakan kebudayaan pada masyarakat Jawa, di mana tindakan magis petungan merupakan suatu usaha untuk mendapatkan kepastian nasib (Romdon, 2002). Bahwa petungan merupakan bentuk seperangkat aturan, pedoman, dan petunjuk perilaku yang sungguh-sungguh dilakukan, dianggap nyata oleh orang yang mempercayainya. Petungan dipahami dan dilaksanakan sebagai bentuk harapan sebagaimana nilai yang dikonstruksikaan setelah menghindari bulan yang dianggap buruk, pada akhirnya mengembalikan kepastiannya pada Tuhan yang Maha Esa.

\section{DISKUSI}

Fenomena waktu-waktu tertentu banyak digunakan untuk melangsungkan pernikahan menunjukkan tindakan memilih dari sekian banyak opsi waktu berdasarkan kalender Jawa, sehingga dari sekian kemungkinan waktu, hanya waktu-waktu dengan 
atribusi harapan baik untuk melangsungkan pernikahan yang dipilih. Atribusi harapan tersebut telah terskema dalam konstruksi tradisi dalam bentuk primbon -petungan Jawa. Pengetahuan atas nilai baik atau buruknya waktu pernikahan tidak selamanya diketahui langsung melalui konstruksi primbon, melainkan pengalaman hidup di tengah-tengah masyarakat yang bertradisi. Sistem tradisi merupakan informasi social, situasi maupun interaksi yang merupakan sumber belajar sosial (Baron \& Byrne, 2004) di mana individu memperoleh pemahaman nilai simbolik dan membentuk skema. Pembentukan skema tentang penentuan hari pernikahan dapat dilihat pada gambar berikut:

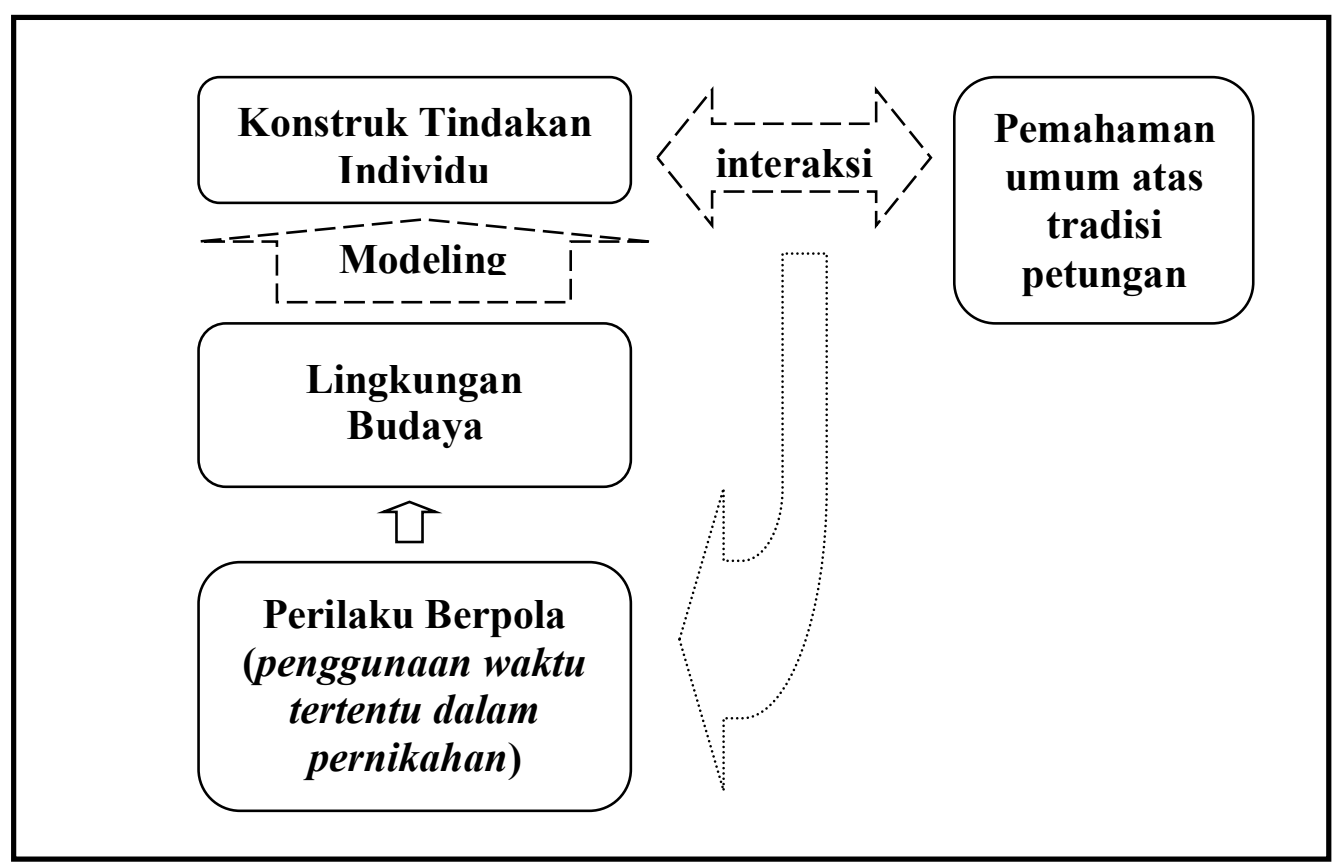

Gambar 1. Pembentukan Skema Pengatahuan atas Penentuan Waktu Pernikahan

Penggunaan waktu-waktu tertentu merupakan tradisi yang terwariskan sebagai informasi sosial dalam satu sistem sosial, menjadi milik bersama melalui representasi diri (Moscovici dalam Hogg \& Voughan, 2005) dipertahankan dengan sistem kepercayaan (Shiraev \& Levy, 2004), hanya bagi mereka yang rasional mulai sedikit menanyakan urgensi penggunaannya. Fakta kultural merupakan pengalaman kehidupan sehari-hari sebagai sosiopsikologis (Matsumoto, 2008) individu, di mana sekumpulan sikap, keyakinan, nilai dan perilaku yang dimiliki bersama dibagikan dari satu generasi ke generasi berikutnya.

Kontinum pengambilan keputusan waktu pernikahan dikonstruksikan berdasarkan pada tradisi yang terus berulang di dalam satu lingkungan kebudayaan dan masyarakat sebagai pengetahuan. Seperti banyak dipaparkan, bahwa penggunaan waktu-waktu tertentu 
merupakan bagian tradisi atau adat, bahkan cenderung common sense. Ketidakpastian yang terjadi di masa mendatang merupakan ancaman terhadap terpenuhinya harapan, Freud (dalam Hall \& Lindzey, 2005) menyebutnya sebagai kecemasan. Kecemasan sebagai mekanisme pertahanan diri sebagai akibat dari bias negativitas (Baron \& Byrne, 2004) sebagai refleksi hal-hal atau informasi dilingkungan yang mengancam. Karenanya informasi negatif lebih mudah diterima dan berpengaruh untuk dihindari terlebih daulu dibandingkan informasi positif. Mekanisme menghindari kecemasan -ketidakpastian nasib disublimasikan pada simbol-simbol budaya seperti atribusi petungan. Selain itu ketidakpastian juga menghasilkan sikap fatalistik, sehingga untuk mereduksi kecemasan karena ketidakpastian ,tradisi petungan dapat menjadi perangkat sublimasi dengan proses kultural-spiritual guna menghindari ketidakpastian dengan pemastian harapan dan kepercayaan berdasarkan pada prinsip kebudayaan. Dengan demikian, dapat digambarkan nilai baik dan buruknya suatu konstruksi petungan dan tindakan menggunakan petungan sebagaimana berikut.

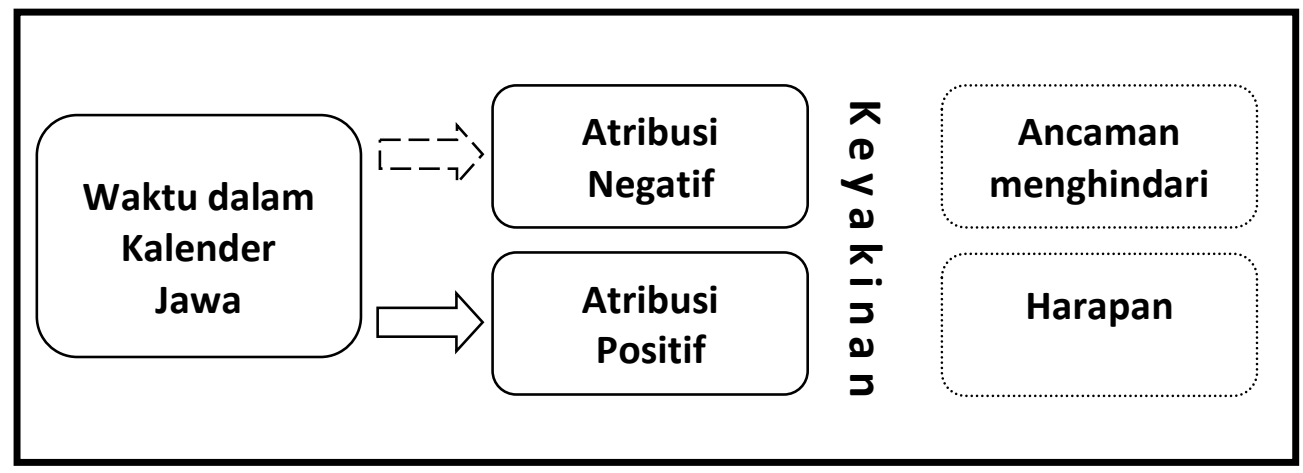

Gambar 2. Konstruk Tidakan Berdasarkan Nilai Simbolik Petungan

Memilih waktu tertentu berdasarkan prinsip dasar petungan merupakan representasi dari harapan psikologis masyarakat Jawa. Seperti dikemukakan Jung (dalam Hall \& Lindzey, 2005) bahwa perlambangan memiliki dua konstruk yaitu retrospektif berdasarkan pada kausalitas pengalaman masa lalu dan juga prospektif, di mana manusia memiliki harapan di masa mendatang. Simbolisme petungan tidak lain karena merepresentasikan menjadi kausal atas kemungkinan terjadinya sesuatu dimasa mendatang (Ritzer \& Goodman, 2007), dengan kata lain melekatnya tradisi menentukan waktu tertentu berdasarkan prinsip nilai simbolik petungan menunjukkan adanya harapan keberlangsungan rumah tangga di kemudian hari berdasarkan pada nilai-nilai atribusi petungan tersebut (lihat gambar 3). 


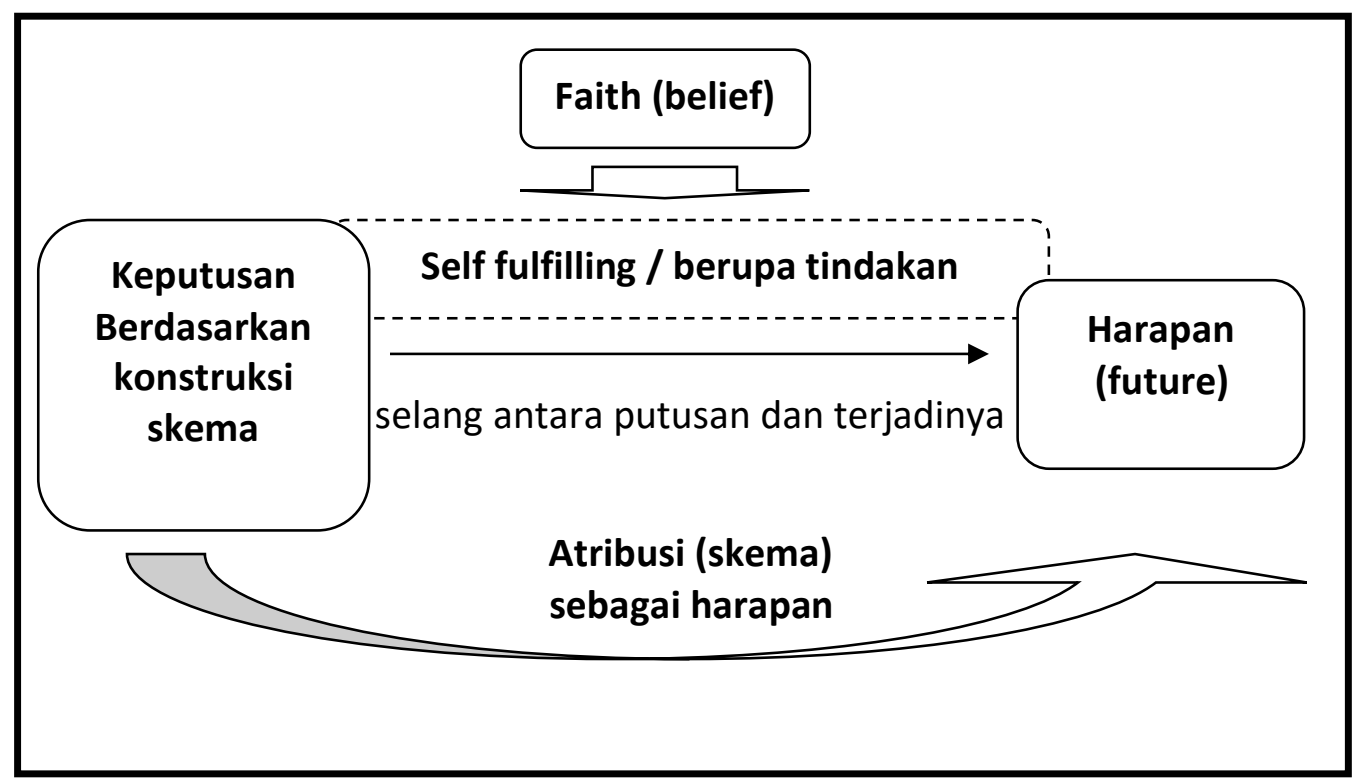

Gambar 3. Alur Pemastian Harapan Psikologis Penggunaan Petungan Jawa

Kepercayaan dalam tradisi petungan pada masyarakat Jawa merupakan komponen psikologis yang penting pada bertahannya satu perilaku atau disebut self perseverance effect, di mana tradisi petungan dipahami dan dipraktikkan untuk dapat memahami lingkungan di luar dirinya dan menjalani kehidupannya. Pengetahuan tentang adanya nasib baik dan buruk yang didasarkan pada penentuan waktu pernikahan telah jauh disediakan masyarakat melalui jalur sosialisasi dan internalisasi. Secara tidak langsung, pengetahuan ini diadopsi sebagai satu hal yang dipercayai membentuk skema dengan efek bertahan (susah berubah) dan memeberi efek pemenuhan harapan (self-fulfilling) dengan membentuk sikap sesuai dengan keyakinan yang diharapkan (Baron \& Byrne, 2004)

Dengan demikian, penggunaan petungan Jawa pada penentuan waktu pernikahan masyarakat Jawa merupakan seperangkat kepercayaan, pemikiran, dan tindakan yang menjadi cara pandang masyarakat Jawa dalam mengkomunikasikan suatu keadaan psikologis tertentu dari diri individu, baik itu harapan, menghindari ancaman, maupun hanya sebatas melaksanakan tradisi. Petungan Jawa seperti halnya perhitungan heroskopis di belahan kebudayaan lain merupakan bahan arketipe dalam psikologi Jungian dan memiliki prinsip sinkronitas dam psychoid, yaitu merealisasikan atau memastikan terjadinya hal yang dipikirkan (Hall \& Lindzey, 2005). 


\section{SIMPULAN DAN SARAN}

\section{Simpulan}

Penelitian ini merupakan studi awal untuk memahami kepercayaan, pemikiran, dan tindakan masyarakat Jawa dalam praktik pengambilan keputusan menggunakan sistem tradisi petungan. Masyarakat Jawa memiliki seperangkat pemikiran simbolis yang memadukan antara pengetahuan dan pemikiran msitik simbolis dalam petungan yang mengatur dan menjadi pertimbangan dalam pengambilan keputusan masyarakat Jawa.

Dari penelitian awal yang dilakukan, diperoleh kesimpulan bahwa petungan merupakan wujud cara pandang dan kearifan lokal masyarakat Jawa sebagai usaha untuk mereduksi kecemasan dan meningkatkan perolehan harapan dengan menghubungkan manusia dengan waktu pernikahan secara heroskopis, dikatakan juga sebagai usaha untuk mendekati -menafsirkan kehendak Tuhan berdasarkan sistem kalender Jawa. Penggunaan petungan dalam penentuan waktu pernikahan menunjukkan representasi psikologis dari ketidakpastian nasib dan harapan di masa mendatang yang dibangun melalui konstruksi petungan.

Spiritualitas petungan merupakan representasi kepercayaan, pemikiran, dan tindakan masyarakat Jawa sebagai usaha manusia untuk memastikan harapan psikologis dan mereduksi kecemasan ketidakpastian dengan memproyeksikan kecemasan dan harapan psikologis pada konstruk kebudayaan.

\section{Saran}

Saran teoritis maupun praktis dai hasil penelitian ini sebagai berikut:

1. Penelitian ini masih sangat mendasar untuk memahami dinamika psikologi indigenous dalam konteks kebudayaan Jawa, sehingga dalam mengembangkan kajian psikologi indigenous, khususnya dalam petungan Jawa, perlu adanya kajian utuh dan mendasar tentang cara pandang, pemikiran dan tindakan orang Jawa terhadap dalam menjalani kehidupannya. 
2. Perlunya epistimologi Jawa sebagai fondasi untuk memahami secara utuh bagaiamana proses mental dan emosi orang Jawa dalam menjalankan sistem adat-istiadat dan tindakan masyarakat Jawa.

3. Saran paraktis pada praktisi dan ilmuan psikologi, memahami secara utuh cara pandang masyarakat Jawam seperti kepercayaan, pemikiran, dan tindakan mereka dalam tradisi petungan, merupakan metode untuk memperoleh gambaran dan memberikan gambaran dalam penangan berbagai kasus dan konseling perkawinan pada masyarakat Jawa.

\section{DAFTAR PUSTAKA}

Baron, R. A., \& Byrne D. (2008). Psikologi sosial (ed. 2) (R. Djuwita, Trans.). Jakarta: Erlangga.

Danandjaya, J. (1988). Antropologi psikologi, teori, metode dan sejarah perkembangannya. Jakarta: Rajawali Press.

Edraswara, S. (2006). Falsafah hidup Jawa. Yogyakarta: Cakrawala.

Hall, C. S. \& Lindzey, G. (2005). Teori-reori psikodinamik. Yogyakarta: Kanisius.

Hariwijaya. (2006). Islam Kejawen. Yogyakarta: Gelombang Pasang.

Hartono. (2016). Critical discourse analysis: Petung Javanese horoscope. Journal of Education and Social Sciences, 4, 318-324.

Hogg, M. A. \& Voughan, G. M. (2005). Social psychology. Boston, MA: Pearson.

Koentjoroningrat. (1990). Pengantar ilmu antropologi. Jakarta: Rineka Cipta.

Listyana \& Hartono (2013). Persepsi dan sikap masyarakat terhadap penanggalan Jawa dalam penentuan waktu pernikahan (Studi kasus Desa Jonggrang Kecamatan Barat Kabupaten Magetan tahun 2013). Diunduh dari http://e-journal.ikippgrimadiun.ac.id/ index.php/JA/article/view/817

Matsumoto. (2008). Pengantar psikologi lintas budaya. Yogyakarta: Pustaka Pelajar.

Mulder, N. (2001). Mistisisme Jawa, ideologi di Indonesia. Yogyakarta: LKiS.

Newcomb, Turner, Converse. (1981). Psikologi sosial (terj). Bandung: Diponegeoro.

Nila, R. N. (2010). Pola keyakinan masyarakat terhadap perhitungan Jawa dalam kegiatan perkawinan. Diunduh dari jurnal-online.um.ac.id/dat a/...artikel2B78A6143733EE28580EFB3439CE84D7.doc

Pakubuwono. (1991). Serat Centini Tembangraras-Amongraga. Jakarta: Balai Pustaka.

Putra, E. I., \& Marina, L. (2008). Konstruksi sosial dan pendekatannya dalam psikologi. Jurnal Psikologi Sosial, 14, 263-272.

Ritzer, G., \& Goodman, D. J. (2007). Teori sosiologi modern (terj.). Jakarta: Kencana.

Romdon. (2002). Kitab Mujarrobat, dunia magi orang Islam Jawa. Yogyakarta: Lazuardi.

Shiraev, E. \& Levy, D. (2004). Cross cultural psychology. Boston, MA: Pearson. 
Smith, J. A. (2009). Dasar-dasar psikologi kualitatif. Bandung: Nusa Media.

Syifudin, A. F. (2006). Antropologi kontemporer. Jakarta: Kencana.

Tjakraningrat, K. P. H. (2008). Kitab Primbon Lukmanakim (Ed. 10). Yogyakarta: Soemodidjoyo Mahadewa. 